Bangl. J. Vet. Med. (2007). 5 (1 \& 2): 59-62

\title{
ROTAVIRAL DIARRHOEA IN KIDS OF BLACK BENGAL GOATS IN MYMENSINGH
}

\author{
B. K. Dey ${ }^{1}$, M. S. Ahmed ${ }^{2}$ and M. U. Ahmed \\ Department of Medicine, Faculty of Veterinary Science, Bangladesh Agricultural University, Mymensingh- \\ 2202, Bangladesh
}

\begin{abstract}
An epidemiological study on rotavirus infection was carried out by examining 484 faecal specimens of kids of Black Bengal goats using RNA polycrylamide-gel-electrophoresis and silver staining (PAGE-ss) technique. Goat rotavirus was detected in 8.68\% (42/484) diarrhoeic faecal specimens. The highest rate of rotavirus infection in goat kids was found in the month of January (13.95\%) and the lowest in August (5.26\%). The rate of rotavirus infection also the highest in winter season $(11.80 \%)$ and the lowest in summer season $(7.10 \%)$. The kids of 7 days to 1-month age group were most frequently found associated with rotavirus infection 13.63\% (12/95), but very young kids which were below 7 days old, were found negative for rotavirus while gradual decreasing infection rate was found with the advancement of age. There was no marked variation in rotavirus infection rate between male and female group of kids. An electrophoretic analysis of rotaviral RNA revealed that kids were infected with rotavirus having only long RNA electropherotypes. The antigenic studies with reference to subgroup and serotypes with specificity and its zoonotic potentials need to be studied further.
\end{abstract}

Key words: Rotaviral diarrhoea, kids, Black Bengal goats

\section{INTRODUCTION}

Rotavirus gastroenteritis is a world wide disease affecting primarily infants, young children and the young of a wide variety of mammalian and avain species (Estes et al., 1983). Rotavirus diarrhoea assume a special importance in developing countries like Bangladesh where malnutrition is common in young animals and children and severe dehydration following rotavirus diarrhoea leads to high rate of mortality as well as significant economic loss to farmers of domestic livestock (Sattar and Springthrope, 1988). The ubiquitous group of viruses contains 11 segmented double stranded RNA (dsRNA) genome, which can be separated into district bands by electrophoresis (Estes et al., 1984). Electropherotyping (the migration pattern of the 11 genome segments following electrophoresis) of rotavirus RNA became an important laboratory and epidemiological technique for identification and characterization of rotavirus as well as its strains, because, this marker is both characteristic and constant for a given virus strain (Estes et al., 1984; Steele and Alexander, 1987). Detail studies on the epidemiology of rotavirus diarrhoea in different mammalian species have been performed in advanced countries but in Bangladesh very limited works have been performed on this context. Thus, the present study was undertaken to define some epidemiological parameters of rotavirus associated diarrhea in kids of Black Bengal goats in Bangladesh.

\section{MATERIALS AND METHODS}

From January to December 2002 faecal specimens were collected from 484 diarrhoeic kids of Black Bengal goats of different areas of Mymensingh district. The collected samples were processed in the Department of Medicine, Faculty of Veterinary Science, Bangladesh Agricultural University, Mymensingh-2202, Bangladesh. The faecal samples were collected directly from the rectum of kids inserting fingers equipped with thin rubber hand gloves, maintaining all aseptic precautionary measures. The faecal materials were kept in a sterile, screw capped container. It was marked for identification. The kids were divided into 4 age groups: 0 days to 7 days of age, 7 days to 1 months of age, 1 month to 6 months of age and older than 6 months.

Present address: ${ }^{1}$ Nachul Veterinary Hospital, Chapai Nawabgonj, ${ }^{2}$ Department of Medicine and Surgery, Barisal Government Veterinary College, Barisal. 
On the other hand, the entire study period was divided into three seasons namely rainy (July-October), winter (November-February) and summer (March-June). The dates of specimen collection, age and sex of patients, important clinical signs and history, environmental situation etc were recorded properly in each case. The faecal specimens were examined for rotavirus by electrophoresis. Viral RNA from faecal specimens were extracted as described by Steele and Alexander (1987) and Dimitrov et al. (1984). Electropherotyping of viral RNA was carried out in $10 \%$ polyacrylamide slab gels and silver staining technique as described by Kobayashi et al. (1989).

\section{RESULTS AND DISCUSSION}

In the present study, rotavirus was detected in 42 of 484 (8.68\%) diarrhoeic faecal specimens which was much lower than the findings of Berrios et al. (1988), Kaminjolo and Adesiyun (1994) but higher than the report (6.18\%) of Talukder (1999). Munoz et al. (1996) detected group A and group B rotaviruses in 8.1\% and $13.5 \%$ diarrhoeic goat kids respectively that was also higher than the present result. This variation might be due to variation in geoclimatic situation, population studied and technique used. Month-wise prevalence of rotavirus infection in goat kids from January to December were 13.95\%, 10.25\%, 7.69\%, 5.4\%, 5.88\%, 8.88\%, 8.10\%, $5.26 \%, 7.14 \%, 7.84 \%, 10.52 \%$ and $12.19 \%$, respectively. The highest prevalence was recorded in January (13.95\%) and the lowest in August (5.26\%) (Fig. 1). Seasonal variation of rotavirus infection in goat kids showed that 7.14\% (12/168), 11.80\% (19/161) and 7.10 (11/155) were found positive in rainy (July-October), winter (November-February) and summer (March-June) seasons respectively (Table 1). The present result showed that the highest rate of infection was found in winter season $(11.80 \%)$ and the lowest in summer (7.10\%).

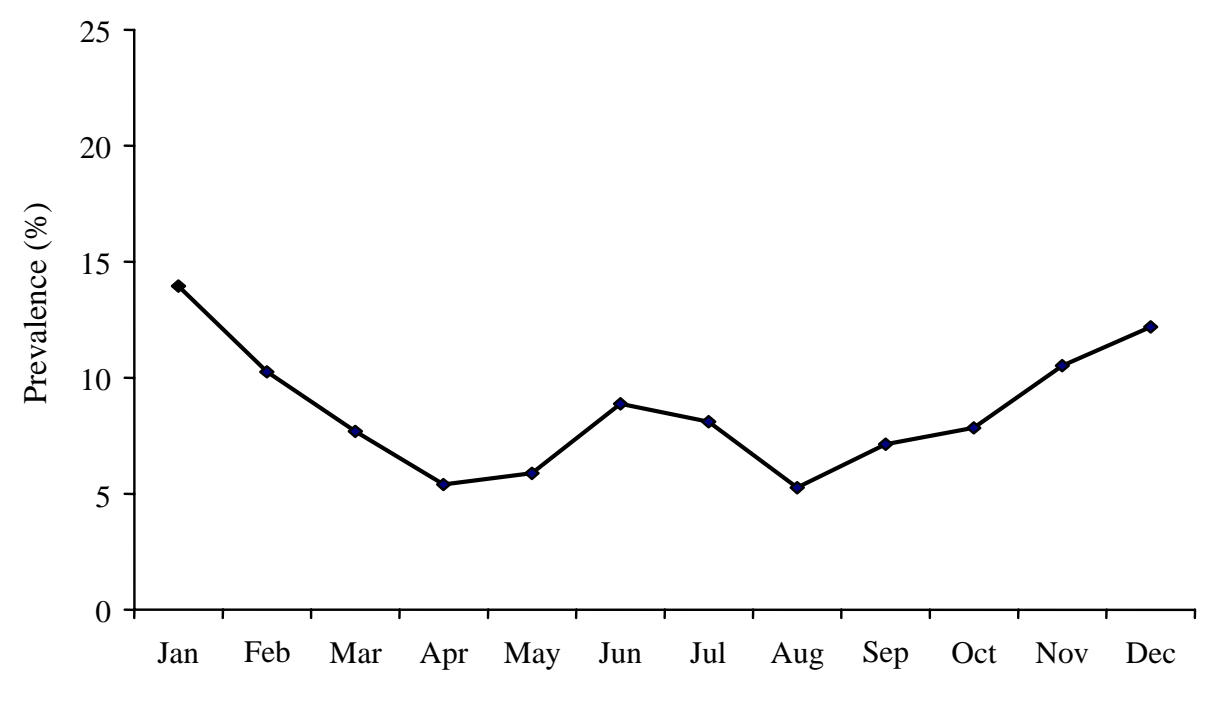

Months of the year 2002

Fig. 1. Month-wise prevalence of rotavirus infection in diarrhoeic Black Bengal goats.

Table 1. The seasonal prevalence of rotaviral diarrhea in kids

\begin{tabular}{|llll|}
\hline Seasons & No. of specimens tested & No. of positive specimens & Prevalence (\%) \\
\hline Rainy (July-October) & 168 & 12 & 7.14 \\
Winter (November-February) & 161 & 19 & 11.80 \\
Summer (March-June) & 155 & 11 & 7.10 \\
Total & 484 & 42 & 8.68 \\
\hline
\end{tabular}




\section{Rotaviral diarrhoea in kids}

There was a little variation in rotavirus infection between male (9.13\%) and female (8.23\%) kids (Table 2). On the other hand, rotavirus was not detected in goat kids less than one week of age which is in conformity with the finding of Abu-El-Hasan (1996). It is assumed that this negative findings is due to ingestion of colostral antibody from mother. The present results revealed that highest prevalence (12.63\%) of rotavirus infection occur in one week to one month age group (Table 3). The most susceptible age group found in this study is almost similar to the finding of Talukder (1999) and Abu-El-Hasan (1996).

Table 2. The prevalence of rotavirus diarrhea in Black Bengal goats in relation to sex showing the seasonal pattern

\begin{tabular}{|l|llllll|}
\hline Seasons & Male & \multicolumn{5}{l|}{ Female } \\
\cline { 2 - 7 } & $\begin{array}{l}\text { No. of } \\
\text { specimens } \\
\text { tested }\end{array}$ & $\begin{array}{l}\text { No. of } \\
\text { positive } \\
\text { specimens }\end{array}$ & $\begin{array}{l}\text { Prevalence } \\
(\%)\end{array}$ & $\begin{array}{l}\text { No. of } \\
\text { specimens } \\
\text { tested }\end{array}$ & $\begin{array}{l}\text { No. of } \\
\text { positive } \\
\text { specimens }\end{array}$ & $\begin{array}{l}\text { Prevalence } \\
\text { (\%) }\end{array}$ \\
\cline { 2 - 7 } Rainy (July-October) & 79 & 6 & 7.59 & 89 & 6 & 6.74 \\
Winter (November-February) & 82 & 10 & 12.19 & 79 & 9 & 11.39 \\
Summer (March-June) & 80 & 6 & 7.5 & 75 & 5 & 6.67 \\
Total & 241 & 22 & 9.13 & 243 & 20 & 8.23 \\
\hline
\end{tabular}

Table 3. The prevalence of rotavirus diarrhea in Black Bengal goats in relation to age

\begin{tabular}{|llll|}
\hline Seasons & No. of specimens tested & No. of positive specimens & Prevalence (\%) \\
\hline Birth -7 days & 46 & 00 & 00 \\
7 days -1 month & 95 & 12 & 12.63 \\
1 month -3 months & 126 & 13 & 10.31 \\
3 months -6 months & 109 & 11 & 10.09 \\
m months - above & 108 & 06 & 5.56 \\
Total & 484 & 42 & 8.68 \\
\hline
\end{tabular}

Out of 42 specimens positive for rotavirus, only 15 showed clearly stained electrophoretic pattern of viral dsRNA, which revealed as 'long' pattern electropherotypes but no 'short' pattern was observed (Fig. 2). This result correlates with the report of Legrottaglie et al. (1993) who found only 'long' electropherotypes.

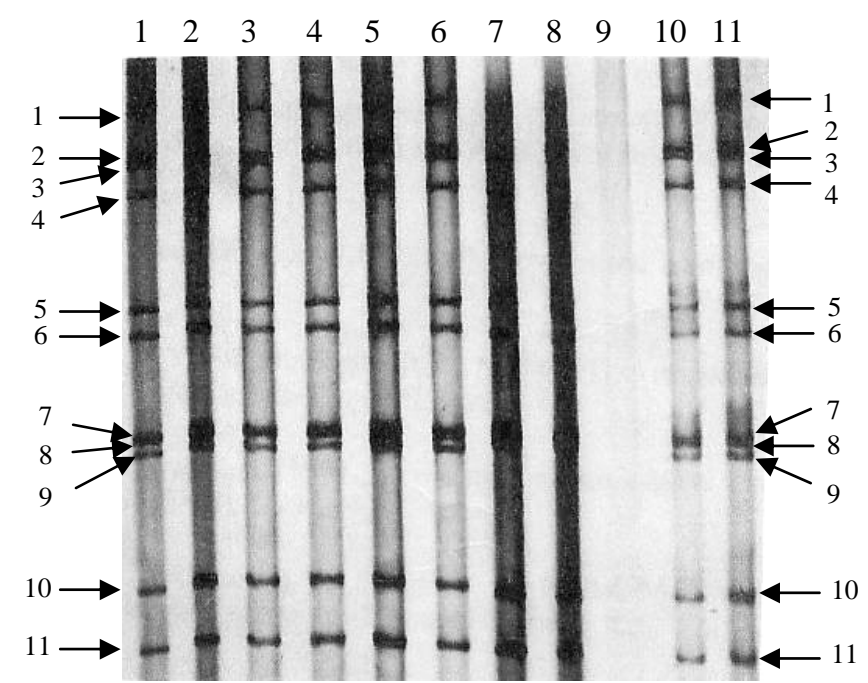

Fig. 2. Polyarcylamide gel electrophoresis of goat rotavirus RNA extracts; showing the characteristic migration patterns of 11 dsRNA of rotavirus segments in positive cases. No. 1 is indicative as a positive control. 
From the present study it may be concluded that rotavirus infection is present throughout the year among goat population of Bangladesh. The occurrence is very low in very young and older goats. Regular feeding of colostral antibody can reduce prevalence of rotavirus infection in young kids. Low incidence of rotavirus diarrhoean in older goats might be due to immunological protection after multiple episodes of rotavirus infection in the same individual. The present study showed some important epidemiological parameters of rotavirus infection in Black Bengal goat kids. However, further epidemiological studies in relation to the strains of virus, antigenic structures with reference to serotypes and zoonotic potentials of rotavirus are necessary before introduction of vaccines against rotavirus diarrhea in goat kids in Bangladesh.

\section{REFERENCES}

1. Abu-El-Hasan DG (1996). Neonatal diarrhea in lambs and goat kids. Veterinary Medical Journal 44: 371-380.

2. Berrios EP, Nunez SF, Celedon VMO, Fiegehen CP and Santibanez ZMC (1988). Detection of rotavirus in goats in San Jose de Maipo, Metropolitan region, Chile, Avances-en-Ciencias-Veterinarieas 3 (2): 98-101.

3. Dimitrov DH, Graham DY, Lopez J, Muchinik G, Velasco G, Stenback WA and Estes MK (1984) RNA electropherotypes of human rotavirus from North and South America. Bulletin, WHO 62 (2): 321-329.

4. Estes MK, Graham, DY and Dimitrov DH (1984). The molecular epidemiology of rotavirus gastroenteritis. Progress in Medical Virology 29: 1-22.

5. $\quad$ Estes MK, Palmer EL and Obijeski JF (1983). Rotaviruses, a review. Current Tropical Microbial Immunology 105: 123184.

6. Kaminjolo JS and Adesiyun AA (1994). Rotavirus in calves, piglets, lambs and goat kids in Trinidad. British Veterinary Journal 150 (3): 293-299.

7. Kobayashi N, Lintag IC, Urasawa T, Taniguchi K, Saniel MC and Urasawa S (1989) Unusual human rotavirus strains having subgroup-1 specificity and long RNA electropherotype. Archives of Virology 109: 11-23.

8. Legrottaglie R, Volpe A, Rizzi V and Agrimi P (1993). Isolation and identification of rotaviruses as etiological agents of neonatal diarrhea in kids. Electrophoretical characterization by PAGE. Microbiologica 16 (3): 227-235.

9. Munoz M, Alvarez M, Lanza and Carmenes P (1996). Role of enteric pathogens in the etiology of neonatal diarrhoea in lambs and goat kids in Spain. Epidemiology of Infection 117 (1): 203-211.

10. Sattar SA and Springthrope VS (1988). Rotaviruses and gastroenteritis in humans. International Journal of Science and Technology 1 (1): 26-58.

11. Steele AD and Alexander JJ (1987). Molecular epidemiology of rotavirus in black infants in South Africa. Journal of Clinical Microbiology 25 (1): 2384-2387.

12. Talukder MRI (1999). Rotavirus diarrhea in human and animals in Mymensingh. M. Sc. Thesis. Department of Medicine, Bangladesh Agricultural University, Mymensingh, Bangladesh. 